\title{
BIODIVERSITY Deconstructing a controversial local range RESEARCH expansion: conservation biogeography of the painted reed frog (Hyperolius marmoratus) in South Africa
}

\author{
Krystal A. Tolley ${ }^{1 \star}$, Sarah J. Davies ${ }^{2}$ and Steven L. Chown ${ }^{2}$
}

${ }^{1}$ Molecular Ecology and Evolution Program, South African National Biodiversity Institute, Private Bag X7, Claremont 7735, South Africa, ${ }^{2}$ Centre for Invasion Biology, Department of Botany and Zoology, Stellenbosch University, Private Bag X1, Matieland 7602, South Africa

${ }^{*}$ Correspondence: Krystal A. Tolley, Molecular Ecology and Evolution Program, South African National Biodiversity Institute, Private Bag X7, Claremont 7735, South Africa. Tel. 21-799-8658; Fax: 21-797-6903; E-mail: tolley@sanbi.org

\begin{abstract}
Local range expansions might either be the response of populations to climate or landscape change, or be caused directly by human intervention. In the latter case the expansion would be considered the first in the steps leading to a biological invasion. In species typically not the subject of human commerce, distinguishing the causes of local range expansions is problematic. Range dynamic theory provides a basis for doing so, and, when used to assess phylogeographical information, can be a powerful conservation biogeographical approach. Here we adopt this approach to resolve the controversial case of the recent range expansion of the painted reed frog (Hyperolius marmoratus) in southern South Africa. Within the last decade, H. marmoratus has spread westward approximately $500 \mathrm{~km}$ from its historical range. This local range expansion could either represent human-mediated jump dispersal, or a response to landscape or climate change. To date, the latter has been assumed, although not universally. Using a phylogeographic approach to investigate these competing hypotheses, a portion of the mitochondrial COI gene was sequenced for individuals from within the historical range ( $n=178)$, and four putatively introduced populations in dams $(n=121)$. There was substantial geographical population structure within the historical range, and these populations were significantly different from the dam populations $\left(\Phi_{\mathrm{ST}}=0.817, P<0.001\right)$. The presence of one or a few dissimilar haplotypes in the dams suggests that introductions are from a number of different sources. This, in conjunction with new survey data, supports the hypothesis that recent establishment of these populations is the result of human-mediated jump dispersal. The impact of this range expansion on ecosystem functioning is unknown, but given the rapid spread of this species and its potential influence on ecosystems, safeguards should be put in place to control further introductions and to restrict the currently invasive populations.
\end{abstract}

\section{Keywords}

Anura, biological invasions, climate change, landscape change, leading edge effect, SAMOVA.

\section{INTRODUCTION}

Biological invasions constitute one of the most significant modern conservation threats (Mack et al., 2000; O’Dowd et al., 2003; Blackburn etal., 2004; Millennium Ecosystem Assessment, 2005). Although the invasion process is typically characterized as involving species not indigenous to a given geopolitical area (Bean, 2007), and is often managed accordingly (Matthews, 2004, 2005), biological invasions may involve any range expansion that is initiated or assisted in an ongoing fashion directly by humans (Pyšek et al., 2004). Thus, the human-mediated movement of organisms indigenous to a given geopolitical area to localities outside their natural distribution within that geopolitical area likewise constitutes the first in the series of steps, whereby a species may eventually become invasive (see Richardson et al., 2000; Richardson \& Pyšek, 2006 for discussion of invasion barriers). Such human-mediated local range expansion is widespread in the game ranching and horticulture industries (e.g. Castley et al., 2001; Groves et al., 2005), where humanassisted translocations, whether accidental or intentional, are common. When local range expansion of this kind is recorded, attributing it to human intervention is straightforward. 
However, when it is found in species that are not commonly the object of human industry or commerce, attribution of its cause is more difficult.

Local range alteration is typically attributed to rapid landscape or climate change (Warren et al., 2001; Didham et al., 2005; Parmesan, 2006). However, the frequency and intensity of movement of humans and goods (McKinney \& Lockwood, 1999; Drake \& Lodge, 2004; Olden et al., 2004) mean that in some species at least, local range expansions must be a consequence of direct human intervention, even if unintentional (Fuller, 2003; Richardson et al., 2003). The conservation actions employed to address landscape- or climate change-mediated, vs. human vector-mediated local range expansions are very different. Conservation interventions to limit range expansions associated with landscape or climate change are often much less tractable than those that are required to reduce human vectoring. Therefore, it is important to distinguish local range expansions that are a response to landscape and climate change from those that are directly mediated by human activities.

Range dynamic theory (see Hengeveld, 1989; Gaston, 2003; Hastings et al., 2005) suggests one way in which this might be done. At least in the initial stages of a human-mediated range expansion, the expansion should more closely resemble a jump dispersal or stratified diffusion process (a combination of jump dispersal and diffusion) (Hengeveld, 1989; Higgins \& Richardson, 1999; Suarez et al., 2001), than the simple diffusive process typically assumed to result from increasing density of individuals accompanied by an increase in range size (Hengeveld, 1994; Gaston, 2003; Hastings et al., 2005). That is, newly established populations should be geographically disjunct from the main range of the species. Moreover, the newly established population need not necessarily include individuals genetically similar to those comprising the closest population that is part of the species' previously recorded range. This is especially likely if the invasion is a pushed, rather than a pulled one (Hastings et al., 2005; Levine et al., 2006).

By contrast, landscape- or climate change-mediated range expansion is more likely to be characterized by diffusion processes (see, e.g. Parmesan, 2006), even though occasional long-distance dispersal events cannot be wholly discounted (e.g. Clark, 1998; Trakhtenbrot et al., 2005). Nonetheless, populations newly established as a consequence of diffusion processes should be genetically similar to those nearest them, with an isolation-bydistance pattern predominating (Kirkpatrick \& Barton, 1997; Lenormand, 2002; Epperson, 2003; Blows \& Hoffmann, 2005), whereas in jump dispersal this will not usually be the case.

Here we apply this essentially conservation biogeographic approach (see Whittaker et al., 2005), using molecular population genetics, to resolve the controversial case of the recent local range expansion of the painted reed frog, Hyperolius marmoratus, in southern South Africa. This Afrotropical species, which typically occupies summer to aseasonal rainfall areas, has recently increased its range to include the winter rainfall region of South Africa, and is becoming abundant in areas previously occupied by the threatened (VU Blab(iii)) congener H. horstockii (IUCN, 2006, but see also Harrison et al., 2001; Braack, 2004). Hence, concerns have been raised about the nature of the H. marmoratus range expansion (Bishop, 2004), especially because it is not clear whether this expansion represents direct human intervention by accidental (or perhaps intentional) transport of the species to areas outside its natural range, or whether climate- and/or landscape-mediated changes in population dynamics lie at the heart of the expansion. If the former applies, a strong case can be made for straightforward and urgent conservation actions, whereas if the expansion represents a natural consequence of changing climates and landscapes, then policy and management interventions are likely to be more complex and their urgency not so immediately obvious.

\section{METHODS}

\section{Background information}

Hyperolius marmoratus is part of the larger $H$. viridiflavus species complex (Wieczorek et al., 2000, 2001), which is widely distributed across tropical and subtropical Africa (Schiøtz, 1999; Channing, 2001). Hyperolius marmoratus is regarded by some investigators as three subspecies based on dorsal colour pattern differences (Fig. 1) but the subspecific status is not straightforward since a great deal of pattern variation and gradation of the different colour morphs occurs at contact zones (Lambiris, 1989; Passmore \& Carruthers, 1979, 1995; Channing, 2001; Bishop, 2004). While the validity of the subspecies is perhaps questionable, for ease of terminology we adopt the term 'subspecies' here when referring to the three colour morphs.

Initial reports of $H$. marmoratus outside its historical range came from the winter rainfall Cape Town area prior to 1995 (A. de Villiers, pers. comm.), at that time indicating a 500-km disjunction between the new population and the closest area thought to be part of the historical range. Thus, the initial data pointed to human-mediated introductions of $H$. marmoratus. Formal surveys conducted during the South African Frog Atlas Project between 1996 and 2003 (Minter et al., 2004) revealed that the species was distributed further westward along the southern South African ('southern Cape') coast than had previously been supposed. Regardless, an apparent $200 \mathrm{~km}$ disjunction remained between the western edge of the major portion of its range and the two populations in Cape Town that had become established by that time. These reports, and similar disjunctions in many other animal species (see, e.g. Brown \& Lomolino, 1998), presumably influenced the decision by the Global Amphibian Assessment to consider H. marmoratus indigenous to all areas in which it is now found (IUCN, 2007). Such a conclusion is largely in keeping with past changes in rainfall seasonality in the southern Cape, current changes therein, and predictions for ongoing change. In the eastern part of the southern Cape, rainfall seasonality shifted in the latter half of the Holocene from a pattern of arid summers to a more aseasonal one (Deacon et al., 1992). This pattern of increasing summer rainfall appears to be continuing and is predicted to carry on in step with global climate change (Midgley et al., 2005). Such a shift in rainfall pattern might easily account for the westwards coastal range expansion 


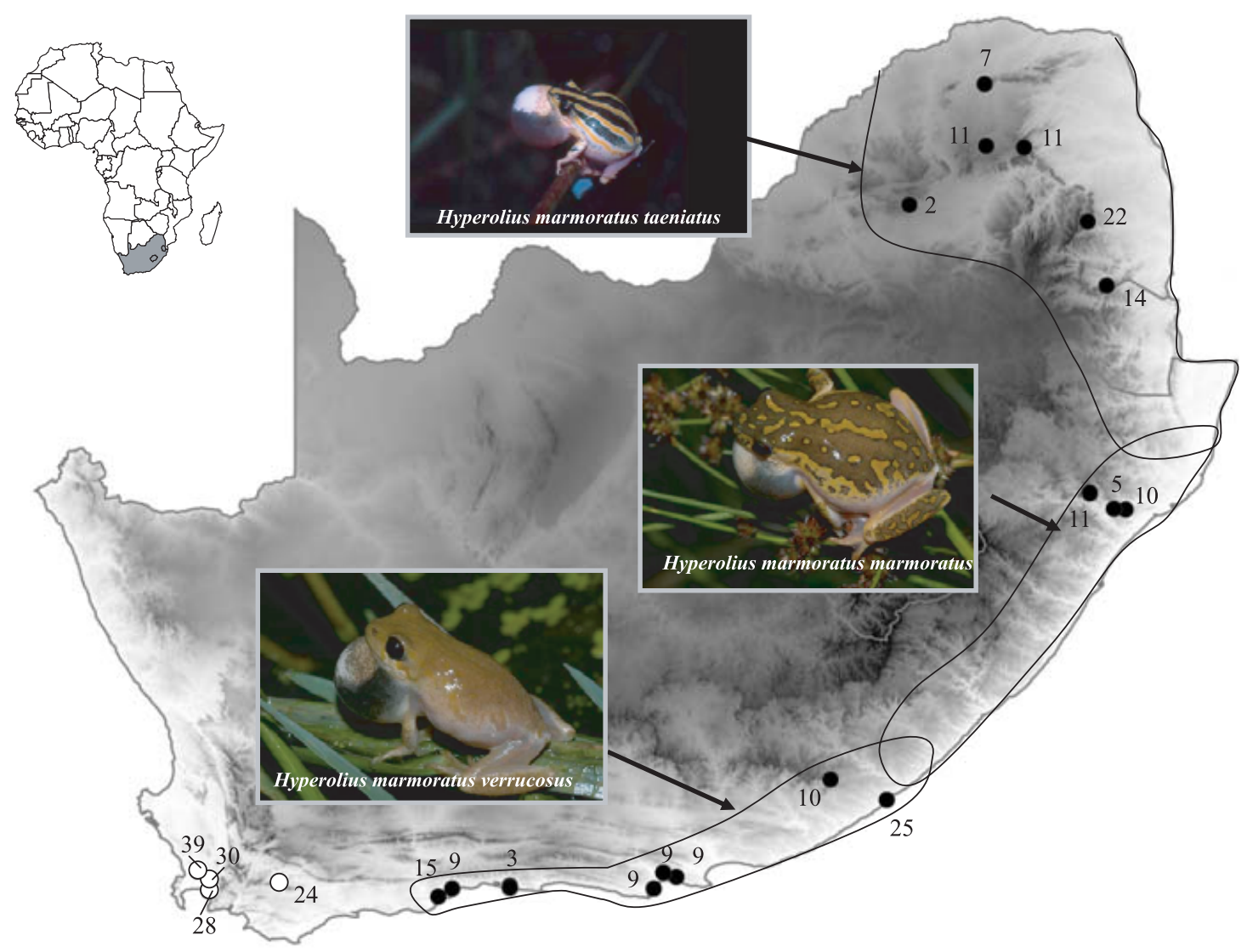

Figure 1 Map of the historical distribution for three subspecies of Hyperolius marmoratus from South Africa. Images show examples of dorsal colour patterns corresponding to each subspecies. Sampling localities are indicated by black circles. Sampling localities outside the historical distribution (dams) are indicated by white circles. Sample sizes are given for each sample locality.

of $H$. marmoratus, given its preference for summer or aseasonal rainfall areas. Moreover, an increase in the number of artificial dams and ponds as a consequence of agricultural expansion and intensification (Rouget et al., 2003; Giliomee, 2006) has increased the availability of suitable habitat. Either singly or in combination, these climate- and landscape-linked changes may have resulted in the establishment of $H$. marmoratus in the Cape Town area.

Thus, on the present biogeographical evidence, local range expansion of the species could plausibly be explained as a natural response to climate and landscape change. By Pyšek et al.'s (2004: Box 1) definition the species would then be considered indigenous to the Western Cape region. However, early reports by workers in the field, and the lack of reports of the species far to the west of its natural range make such a conclusion tenuous, and suggest that the species has been introduced to the region by humans (Bishop, 2004). It is these competing hypotheses that we investigate here.

\section{Species and sample collection}

Frogs were collected by hand during the 2004/5 summer breeding season (October to February) from 18 sampling sites within the historical range, and from four artificial water bodies (hereafter 'dams') outside the historical range (Fig. 1, see Appendix S1 in Supplementary Material). All frogs were photographed and the dorsal colour pattern was recorded. Toe clippings were taken from frogs collected within the historical range $(n=178)$, and the frogs released after sampling. All frogs from dams were retained as specimens (currently held by KAT at the South African National Biodiversity Institute) and toes were clipped from these specimens for molecular analysis $(n=121)$. All tissues were stored in $96 \%$ ethanol.

\section{Genetic analysis}

Total genomic DNA was extracted using a standard digestion buffer containing 5\% Chelex ${ }^{\mathrm{TM}} 100$ (Bio-Rad Laboratories) and $10-15 \mu \mathrm{L}$ proteinase- $\mathrm{K}(10 \mathrm{mg} / \mathrm{mL})$. Digestions were carried out for a minimum of $1 \mathrm{~h}$ at $55^{\circ} \mathrm{C}$, followed by $10 \mathrm{~min}$ at $95^{\circ} \mathrm{C}$. The digest was spun down, the supernatant removed, and used directly in polymerase chain reaction (PCR). A portion of the mitochondrial cytochrome-oxidase subunit I (COI) was amplified in $25 \mu \mathrm{L}$ reaction volumes containing $5-8 \mu \mathrm{L}$ of DNA extract, $0.25 \mu \mathrm{M}$ of each primer, $0.2 \mathrm{~mm}$ dNTPs, $2.5 \mathrm{~mm} \mathrm{MgCl}_{2}$, $1 \times$ thermophilic buffer ( $50 \mathrm{~mm} \mathrm{KCl,} 10 \mathrm{~mm}$ Tris- $\mathrm{HCl}, \mathrm{pH} 9$ ), and 0.25 U Super-Therm Taq DNA polymerase. The primers initially used for amplification (L1490 and H2198) were designed to 
amplify the COI gene in arthropods (Folmer et al., 1994). After initial sequences were obtained, species-specific primers were designed: 5' L5424 GGC CTT AGC TTA TTA ATC C-3' and H6023 5'-ATA GAG AAT TGG ATC TCC TC-3' (primer sequences aligned to Xenopus laevis; Roe et al., 1985) and used thereafter. The PCR thermal profile was $95^{\circ} \mathrm{C}$ for $1 \mathrm{~min}$, followed by 35 cycles of $35 \mathrm{~s}$ at $95^{\circ} \mathrm{C}, 30 \mathrm{~s}$ at $55^{\circ} \mathrm{C}$, and $1 \mathrm{~min}$ at $72{ }^{\circ} \mathrm{C}$, with a final extension at $72{ }^{\circ} \mathrm{C}$ for $5 \mathrm{~min}$. An aliquot of the PCR product was electrophoresed on a $1 \%$ agarose gel containing ethidium bromide, and visualized by ultraviolet light. PCR products were cycle sequenced using a fluorescently labelled dye-terminator kit (Applied Biosystems, Foster City, CA, USA), purified with Sephadex spin columns, and analysed on an Applied Biosystems 3100 genetic analyser. MacClade 4.0 (Maddison \& Maddison, 2000) was used to identify haplotypes. Sequences have been submitted to GenBank (Accession nos EU53175-53198).

A spatial analysis of molecular variance (sAmova) was carried out to determine a priori clustering of the sampling sites within the historical range (Dupanloup et al., 2002). The samova takes into consideration the geographical locations of sites, and maximizes the proportion of genetic variance among $K$ groups (Dupanloup et al., 2002). As such, this analysis was useful for statistically differentiating between historically isolated groups that presumably represent populations. The sAmova was run with several different possible group structures (values of $K=2$ through 10) to determine the maximum value for $F_{\mathrm{CT}}$ (the maximized proportion of total genetic variance due to differences between groups).

Haplotype $(h)$ and nucleotide $(\pi)$ diversity were estimated in ARLEQUIN for each subspecies, each population (predetermined by SAMOVA), and each dam. An analysis of molecular variance (AMOVA) was run in ARLEQUIN 2.0 to estimate levels of variation $\left(F_{\mathrm{ST}}\right.$ and $\left.\Phi_{\mathrm{ST}}\right)$ among the populations and the dams (Schneider et al., 2000). The estimate of $\Phi_{\mathrm{ST}}$ was made using the Tamura-Nei model of evolution (equal rates for all sites) as determined by Modeltest 3.6 (Posada \& Crandall, 1998). The significance of the resultant $F$ statistics was tested by running 100,000 permutations of the data set.

Relationships among haplotypes were examined with a median-joining network in Network 4.1 (Bandelt et al., 1999). In addition, a phylogenetic analysis was run on the set of all unique haplotypes, using an unweighted parsimony analysis with a heuristic search and 1000 random addition replicates (DELTRAN optimization; characters unordered; TBR branch swapping). A search of GenBank for an appropriate outgroup taxon revealed no COI sequences in the family Hyperoliidae. A member of the Ranidae (Ceratobatrachus guentheri, GenBank Accession no. AY883979) was chosen as an alternative outgroup, as the Ranidae and Hyperoliidae are both placed in the superfamily Ranoidea (Frost et al., 2006). Confidence in the nodes was assessed by 1000 bootstrap replicates with random addition of taxa.

A coalescent approach was used to investigate levels of gene flow (M) between populations. An infinite site model was used, and the Markov Chain Monte Carlo simulation was allowed to run for 10 million generations, with 10\% burn-in (Nielsen \&
Wakeley, 2001). Data were submitted pairwise by population to the remote computer cluster running the program MDiv at Cornell University via internet upload (http://cbsuapps.tc.cornell.edu/ mdiv.aspx). Posterior distributions for $\mathrm{M}$ were plotted, and $\mathrm{M}$ was approximated as the value with the greatest posterior probability. Three independent runs were made for each population pair, and the mean $\mathrm{M}$ from these runs was plotted against geographical distance for each pair. The relationship between $M$ and geographical distance was examined using a Mantel test in the program Mantel for Windows version 1.18 (Calvalcanti, 2005).

\section{RESULTS}

Most individuals collected from within the historical range of the subspecies, H. m. verrucosus $(n=89), H . m$. marmoratus $(n=22)$, and H. m. taeniatus $(n=67)$, were found to have the general colour pattern expected from subspecies accounts in the literature (Passmore \& Carruthers, 1979, 1995; Minter et al., 2004). A minority of both juvenile and adult individuals were plain brown (from $0 \%$ to $20 \%$ per sample site), a colour morph that was absent from only the Soutpansberg H. m. taeniatus site. Every individual from the dams in Stellenbosch $(n=30)$ and Villiersdorp $(n=24)$ matched the H.m. verrucosus morph, whereas all individuals from the Strand dam $(n=28)$ matched the H. m. taeniatus morph. In the Durbanville dam $(n=39)$, two colour morphs were found in approximately equal frequencies (H. m. verrucosus $(n=19)$, and H.m. marmoratus $(n=20))$, suggesting the presence of both subspecies together in Durbanville. In addition, a single individual of the H. m. taeniatus morph was later found by A. de Villiers, but was not sampled for DNA.

\section{Genetic analysis}

A total of 24 unique haplotypes was found, and the two most common haplotypes (KTH402 and KTH415) had notably high frequencies in H. m. verrucosus (see Appendix S1). Hyperolius m. taeniatus had significantly higher haplotype diversity than the other subspecies, but values were not significantly different between $H$. m. verrucosus and H. m. marmoratus (Table 1). The SAMova revealed that the 18 sampling sites within the historical range can be grouped into six populations: four $H$. m. taeniatus populations, one $H$. m. marmoratus population, and one $H$. $m$. verrucosus population. The presence of these six populations is indicated by a dramatic increase in $F_{\mathrm{CT}}$ followed by a slightly increasing plateau reaching a peak at six to seven groups (Fig. 2). These six to seven groups were assumed to represent 'natural populations' within the historical range of the species, and we adopt six as the most parsimonious number of populations (Fig. 2).

The analysis of molecular variance (AMOVA) resulted in significant differences between every pair of subspecies, and between every pair of populations (Tables 2 and 3) within the historical range for $F_{\mathrm{ST}}$ and $\Phi_{\mathrm{ST}}$ (overall $F_{\mathrm{ST}}=0.50, \Phi_{\mathrm{ST}}=0.82$, $P<0.001)$. All dams were significantly different from each other (Table 3) except Stellenbosch and Villiersdorp which had an 


\begin{tabular}{lrrll}
\hline & $n(a)$ & $\mathrm{H}$ & $h$ & $\pi$ \\
\hline Subspecies & & & & \\
verrucosus & $89(9)$ & 8 & $0.43(0.372-0.494)$ & $0.0010(0.0001-0.0020)$ \\
marmoratus & $22(3)$ & 6 & $0.53(0.412-0.653)$ & $0.0018(0.0003-0.0032)$ \\
taeniatus & $68(6)$ & 13 & $0.88(0.853-0.901)$ & $0.0130(0.0061-0.0198)$ \\
$\quad$ Soutpansberg & $7(1)$ & 1 & 0.00 & 0.0000 \\
$\quad$ Polokwane & $11(1)$ & 2 & $0.50(0.400-0.600)$ & $0.0010(0.0000-0.0020)$ \\
Stanford Lake & $11(1)$ & 3 & $0.58(0.440-0.724)$ & $0.0013(0.0001-0.0025)$ \\
$\quad$ Southern & $38(3)$ & 10 & $0.87(0.844-0.899)$ & $0.0165(0.0078-0.0252)$ \\
Dams & & & & \\
$\quad$ Villiersdorp & $24(1)$ & 1 & 0.00 & 0.0000 \\
$\quad$ Strand & $28(1)$ & 1 & 0.00 & 0.0000 \\
$\quad$ Stellenbosch & $30(1)$ & 1 & 0.00 & 0.0000 \\
$\quad$ Durbanville & $39(1)$ & 3 & $0.55(0.500-0.590)$ & $0.0012(0.0001-0.0023)$ \\
\hline
\end{tabular}

Table 1 The number of individuals $(n)$, number of sites sampled $(a)$, number of haplotypes $(\mathrm{H})$, haplotype diversity $(h)$, and nucleotide diversity $(\pi)$ with $95 \%$ confidence intervals in parentheses, for Hyperolius marmoratus. Data are shown for the three subspecies (H. m. verrucosus, $H$. m. marmoratus, and H. m. taeniatus), and frogs from dams in the Western Cape Province. The four populations of $H$. m. taeniatus identified by spatial analysis of molecular variance are listed separately (Soutpansberg, Polokwane, Stanford Lake, Southern).

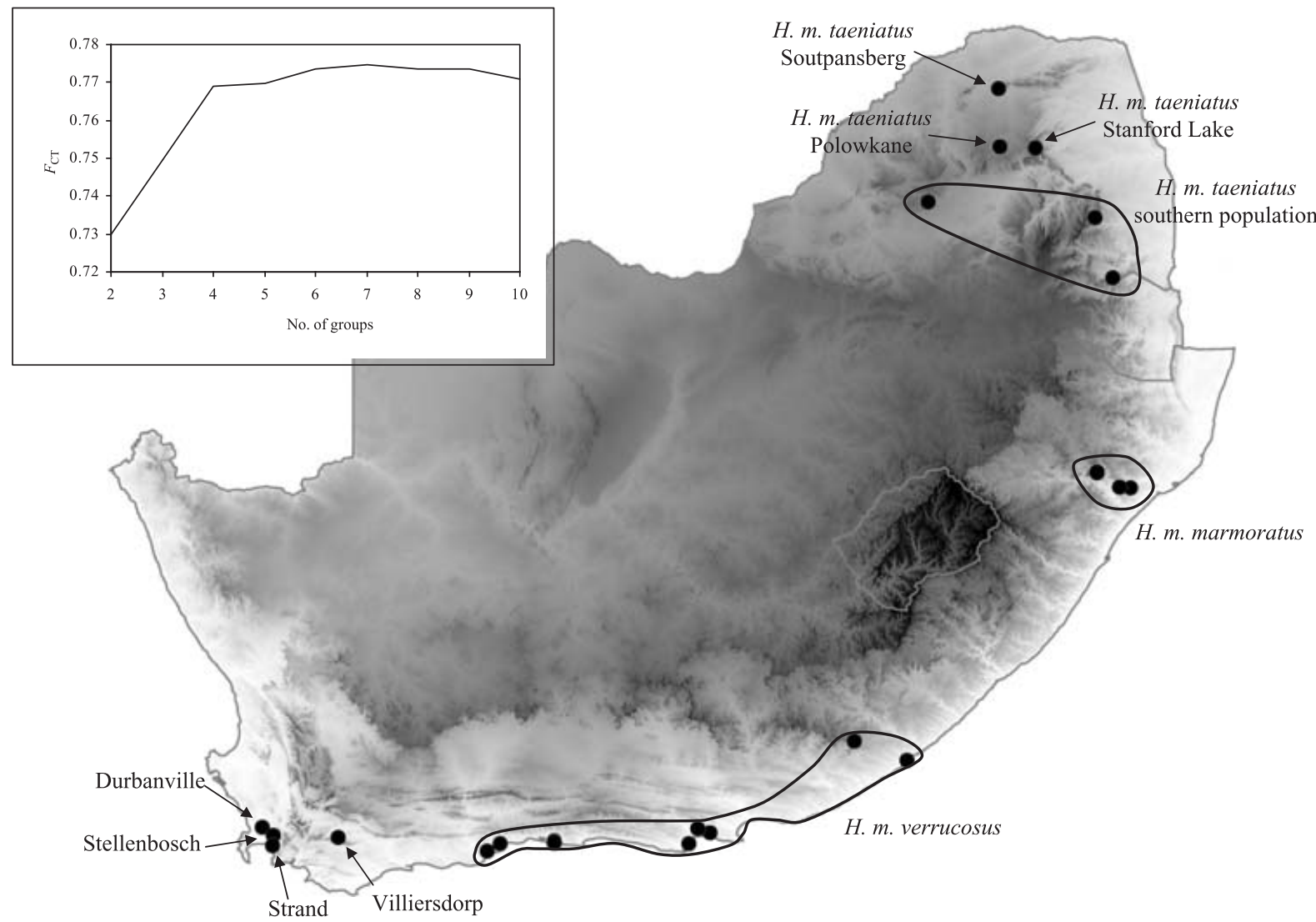

Figure 2 Geographical distribution of the six populations of Hyperolius marmoratus as indicated by the spatial analysis of molecular variance (samova) results. Populations are H. m. verrucosus, H. m. marmoratus, Southern H. m. taeniatus, and three separate northern H. m. taeniatus populations (Soutpansberg, Polokwane, and Stanford Lake). Inset: Relationship between $F_{\mathrm{CT}}$ and the number of Hyperolius marmoratus populations input into the samova. At $K=6$ populations, $F_{\mathrm{CT}}=0.774$.

identical haplotype composition. The Amova also showed significant frequency differences between all but one of the dams and the natural populations (Table 3 ), with only $H$. $m$. verrucosus and the Villiersdorp dam not significantly different $\left(\Phi_{\mathrm{ST}}=0.03\right.$, $P=0.086)$. This result seems to be due to a lack of statistical power, given that all frogs from Stellenbosch $(n=30)$ and Villiersdorp $(n=24)$ had the same haplotype yet frogs from the
Stellenbosch dam were significantly different from $H$. m. verrucosus (Table 3).

The parsimony analysis showed 20 informative characters in the data set, and produced six equally parsimonious trees that differed only by terminal branch swapping $(\mathrm{CI}=0.96$, $\mathrm{RI}=0.95$ ). Two well-supported clades were found (tree not shown), each with $>90 \%$ bootstrap support. These clades were 
Figure 3 Median-joining haplotype networks for the two Hyperolius marmoratus clades (A and B). The sizes of the circles indicate the frequency of the haplotypes, and the length of the branches indicates distance between haplotypes. The frequency at which haplotypes occur by colour morph is indicated by black (H. m. taeniatus), grey (H. m. marmoratus), and white (H. m. verrucosus) circle proportions. Haplotypes found in each of the dams are shown by arrows. Also shown (inset) is the network structure for only the H. $m$. verrucosus subspecies, which is a subset of Clade B.
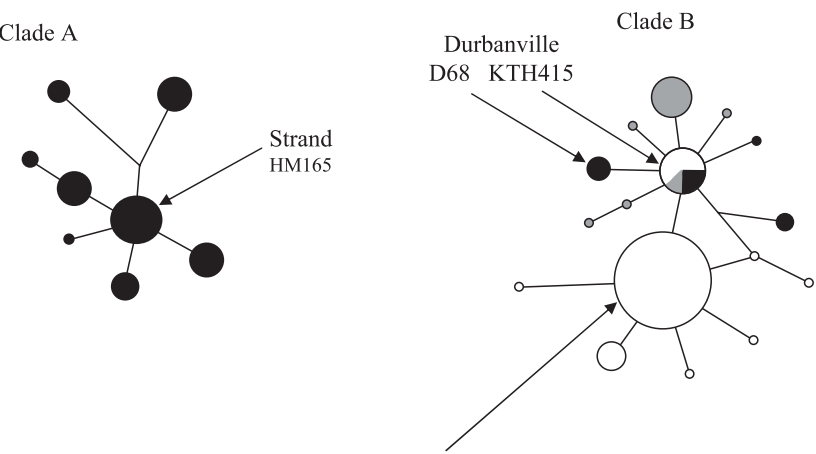

Stellenbosch, Villiersdorp \& Durbanville KTH402

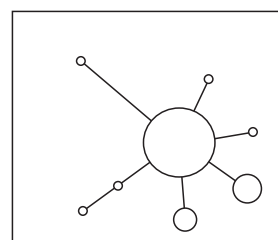

Inset: $H . m$. verrucosus only
Table 2 Analysis of molecular variance results for three subspecies of Hyperolius marmoratus. $F_{\mathrm{ST}}$ values are given above the diagonal and $\Phi_{\mathrm{ST}}$ values below it. All values were significant at $P<0.001$ (overall $F_{\mathrm{ST}}=0.354, \Phi_{\mathrm{ST}}=0.725$ ).

\begin{tabular}{llll}
\hline & taeniatus & marmoratus & verrucosus \\
\hline taeniatus & - & 0.262 & 0.321 \\
marmoratus & 0.631 & - & 0.526 \\
verrucosus & 0.747 & 0.675 & - \\
\hline
\end{tabular}

also observed in the median-joining network (separated by 12 mutational steps, link not shown; Fig. 3). Clade A contained only individuals from the $H$. m. taeniatus subspecies, including all individuals from the three northern $H$. m. taeniatus populations and the majority (61\%) of individuals from the Southern H. $m$. taeniatus population. Clade B contained a mixture of individuals from all of the subspecies, although $H . m$. verrucosus and marmoratus dominate this clade (Fig. 3, see Appendix S1). A separate network was constructed for the $H$. m. verrucosus population, to investigate the possibility of recent demographic changes in this subspecies. The network showed a star-shaped pattern (Fig. 3), consistent with that expected in a population that has undergone a recent range expansion.

All individuals from the Strand dam were identical for both mitochondrial haplotype (HM165) and colour morph (H. m. taeniatus) suggesting that this dam was colonized by $H . m$. taeniatus (Fig. 3, see Appendix S1). All individuals from Stellenbosch and Villiersdorp were also identical for haplotype (KTH402) and colour morph (H. m. verrucosus), suggesting that both dams were colonized by H. m. verrucosus (Fig. 3, see Appendix S1). All three morphs were found in the Durbanville dam, although the H. m. taeniatus morph was represented by

Table 3 Analysis of molecular variance results for each population of Hyperolius marmoratus. $F_{\mathrm{ST}}$ values are given above the diagonal and $\Phi_{\mathrm{ST}}$ values below it. All values were significant at $P<0.05$ except where indicated by ns (overall $F_{\mathrm{ST}}=0.498, \Phi_{\mathrm{ST}}=0.817, P<0.001$ ).

\begin{tabular}{|c|c|c|c|c|c|c|c|c|c|c|c|}
\hline & & 1 & 2 & 3 & 4 & 5 & 6 & 7 & 8 & 9 & 10 \\
\hline 1. taeniatus & Soutpansberg & - & 0.697 & 0.656 & 0.405 & 0.631 & 0.651 & 1.000 & 0.596 & 1.000 & 1.000 \\
\hline 2. & Polokwane & 0.907 & - & 0.383 & 0.122 & 0.477 & 0.547 & 0.831 & 0.467 & 0.854 & 0.473 \\
\hline 3. & Stanford Lake & 0.900 & 0.575 & - & 0.209 & 0.447 & 0.527 & 0.804 & 0.442 & 0.830 & 0.776 \\
\hline 4. & Southern & 0.351 & 0.228 & 0.280 & - & 0.271 & 0.315 & 0.456 & 0.208 & 0.482 & 0.370 \\
\hline 5. marmoratus & & 0.958 & 0.951 & 0.950 & 0.506 & - & 0.526 & 0.743 & 0.430 & 0.767 & 0.760 \\
\hline 6. verrucosus & & 0.971 & 0.967 & 0.967 & 0.680 & 0.675 & - & 0.093 & 0.090 & 0.103 & 0.701 \\
\hline 7. Dams & Villiersdorp & 1.000 & 0.990 & 0.988 & 0.544 & 0.773 & $0.027 \mathrm{~ns}$ & - & 0.319 & $0.000 \mathrm{~ns}$ & 1.000 \\
\hline 8. & Durbanville & 0.968 & 0.962 & 0.961 & 0.555 & 0.522 & 0.152 & 0.323 & - & 0.343 & 0.695 \\
\hline 9. & Stellenbosch & 1.000 & 0.992 & 0.990 & 0.569 & 0.795 & 0.034 & $0.000 \mathrm{~ns}$ & 0.347 & - & 1.000 \\
\hline 10. & Strand & 1.000 & 0.473 & 0.796 & 0.305 & 0.974 & 0.974 & 1.000 & 0.976 & 1.000 & - \\
\hline
\end{tabular}




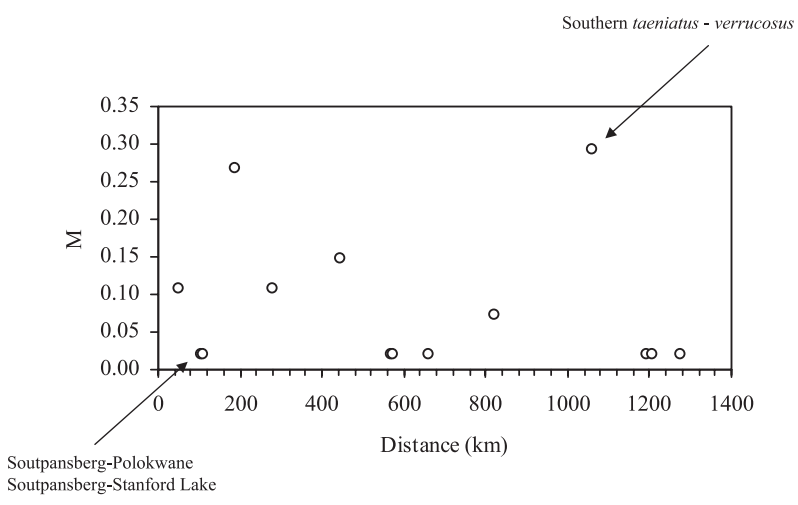

Figure 4 Rates of gene flow (M) between populations of Hyperolius marmoratus plotted against distance $(\mathrm{km})$ between populations. Only populations within the historical distribution are shown.

only a single individual. Three haplotypes were present in the Durbanville dam, but two haplotypes dominated (KTH402 56\%; KTH415 - 39\%; D68 - 5\%).

The coalescent analysis showed that gene flow (M) was generally low among geographically distant populations (see Appendix S2 in Supplementary Material). However, no overall association between $\mathrm{M}$ and geographical distance was found $(r=-0.18$, ns), suggesting that gene flow does not follow a simple pattern of isolation-by-distance. One population pair (southern H. m. taeniatus and $H . m$. verrucosus) had relatively high gene flow despite the large distance between them (Fig. 4, see Appendix S2). In addition, two pairs (H. m. taeniatus from Soutpansberg with those from both Polokwane and Stanford Lake) had relatively low gene flow despite the small geographical distance between them (Fig. 4, see Appendix S2). Low values of M were consistently estimated between the populations within the historical range and those from the dams (see Appendix S2).

\section{DISCUSSION}

\section{Population structure within the historical range}

Hyperolius marmoratus from South Africa fall into two wellsupported clades, and the three subspecies (H. m. taeniatus, H. m. marmoratus, and H.m. verrucosus) are each not monophyletic. This suggests that there is either contemporary gene flow between the subspecies, or that lineage sorting is incomplete and ancestral polymorphisms have been retained. Previous views that much variation exists within subspecies and a gradation of the different colour morphs at contact zones (Channing, 2001; Bishop, 2004) are supported by the present morphological and genetic results. Indeed, at the population level the species shows substantial structure. The northernmost subspecific form, H. m. taeniatus, is the most genetically distinct, and the SAMOVA suggests this form comprises four populations, with the Southern population showing the greatest variation.

Some of the geographical structure was unexpected given the distances between sampling areas. For example, the coalescent analysis indicated low gene flow between $H . m$. taeniatus populations from Soutpansberg, Stanford Lake, and Polokwane, despite their geographical proximity. Although small sample sizes could have influenced these results, complex spatial structure over short distances has been found in other amphibians, and is certainly characteristic of some aquatic or semiaquatic species separated by watersheds (e.g. Funk et al., 2005; Measey et al., 2007a). In the present case, quite different watersheds are indeed characteristic of the areas surrounding Polokwane, Soutpansberg, and the Southern population (Dollar, 1998), but further microgeographical sampling will be required to reveal the extent to which this geographical structure is associated with the region's hydrology.

\section{Holocene range expansion}

Hyperolius m. verrucosus appears to be comprised of a single population, with low genetic diversity and high frequency of a single haplotype. Such a pattern is often interpreted as representing the leading edge of a recent radiation into a new geographical region (Hewitt, 1996, 2000), and in this case would suggest that $H$. m. verrucosus has recently occupied its current natural range. A historical range expansion may have been associated with climatic changes over the past several thousand years. Dry summers in the eastern part of the southern Cape fynbos region persisted throughout much of the Holocene, and only over the last 5000 years have moist summers (associated with an aseasonal or weakly bimodal rainfall pattern) become characteristic of the area (Deacon et al., 1992; Mucina \& Rutherford, 2006). For a spring or summer breeding frog species that is associated with standing water and temporary pools (Bishop, 2004), the development of an aseasonal rainfall pattern in an area previously dominated by arid summers would have provided an opportunity for range expansion. Additionally, with European colonization of the Western Cape from 1652 onwards, it seems likely that ongoing landscape change associated with the construction of permanent irrigation dams and ponds as agriculture intensified across the region (Rouget et al., 2003; Giliomee, 2006) would simply have complemented these opportunities. Ongoing trends of increasing summer rainfall in the western part of the southern Cape would certainly have facilitated a westward range expansion by this species. In line with these arguments, the median-joining network for H. m. verrucosus shows a starshaped pattern (Fig. 3), which is characteristic of the leading edge of a recent expansion (Hewitt, 1996, 2000). In addition, a post-hoc test (using ARLEQUIN 2.0) of mutation-drift equilibrium (Fu, 1997) shows that H. m. verrucosus is strongly out of equilibrium $\left(F_{S}=-5.8, P<0.01\right)$, suggesting that it has undergone an extreme demographic change in the form of a recent expansion in its historical range.

\section{Human-mediated jump dispersal?}

Although Holocene climate change in the region provides a plausible explanation for the predominant genetic signature, the primary question remains the likely origin of the putatively introduced populations in the Western Cape. For Strand, the 


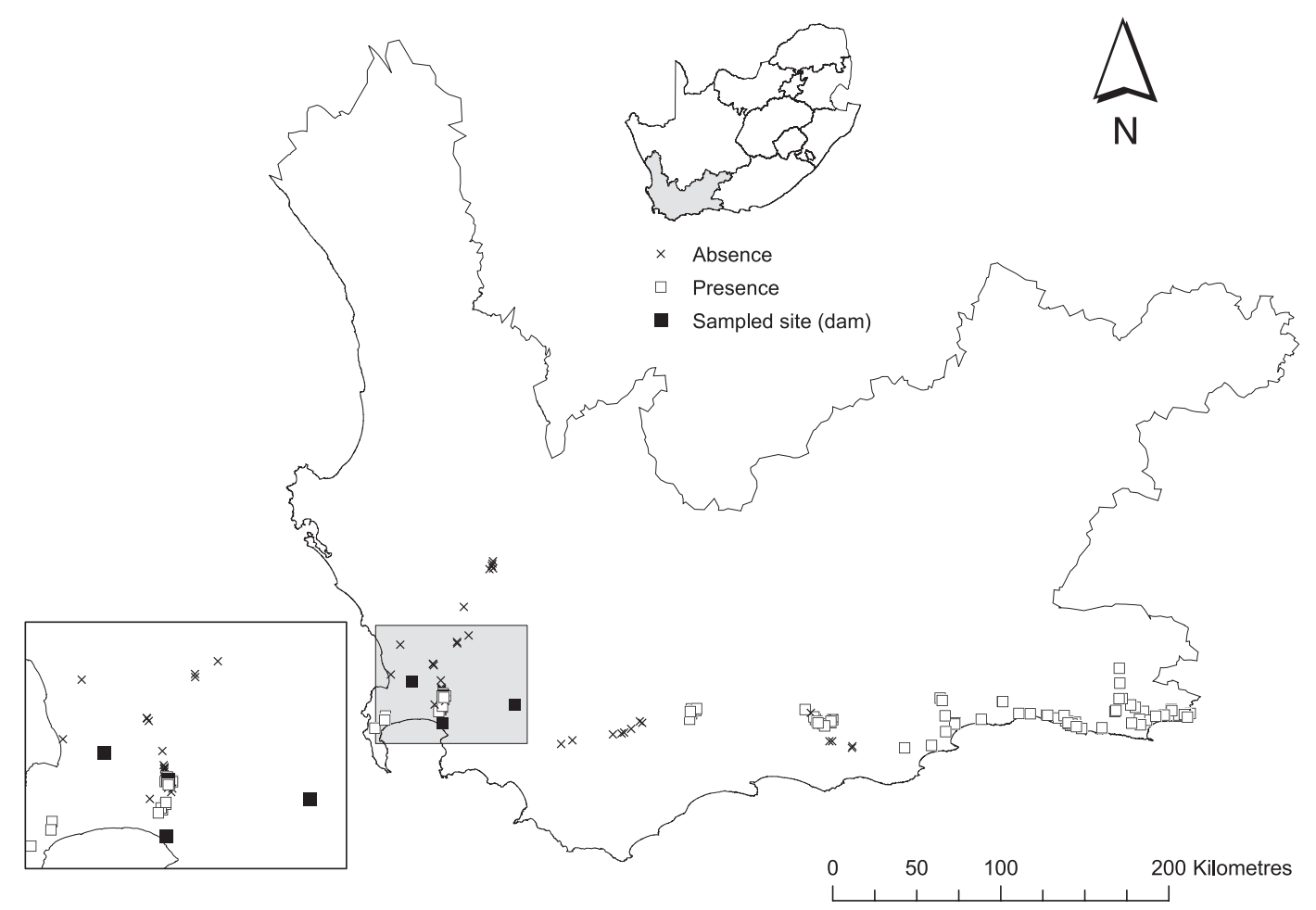

Figure 5 Known geographical range of Hyperolius marmoratus in the Western Cape Province, South Africa, showing the locations in which putatively introduced populations occur. Data are from Western Cape Nature Conservation Board (CapeNature) Scientific Services, the South African Frog Atlas Project (SAFAP) and authors' surveys.

situation is clear, as all individuals had the common H. m. taeniatus haplotype (HM165) and colour pattern. Because HM165 occurs in three of the four H. m. taeniatus populations (see Appendix S1) it is not possible to pin-point the original source of the introduction. Regardless, it is clear that these frogs originated from a naturally occurring set of populations more than $1500 \mathrm{~km}$ away, with no records of these populations in the intervening area, despite a thorough recent survey (Minter et al., 2004). Therefore, the Strand population can be considered nonindigenous, and the consequence of human-mediated jump dispersal (Hengeveld, 1989; Suarez et al., 2001).

In the case of the Villiersdorp and Stellenbosch dams, a natural dispersal event must be a consideration, given that all individuals in these dams displayed the H. m. verrucosus colour pattern, and were of the most common H.m. verrucosus haplotype (KTH402). However, the presence of only a single haplotype in two widely separated dams would be extremely unusual in the case of a natural range expansion. The genetic signature does not match the 'star-shaped phylogeny' which is expected for populations that have undergone a range expansion (Hewitt, 1996, 2000). Thus, it is unlikely that populations in these dams form part of a continuous diffusion-type, natural range expansion process (Hengeveld, 1994; Gaston, 2003). In consequence, natural colonization of the dams can be discounted despite evidence of ongoing climate and landscape changes in the region (Rouget et al., 2003; Midgley et al., 2005; Giliomee, 2006).
The Villiersdorp population was first noticed in December 2003, and the Stellenbosch population a year later (K.A.T., unpublished data, and A.A. Turner, unpublished data). Assuming that these initial reports represent the earliest occurrences, it is unlikely that one dam was colonized first, and that frogs subsequently spread across the mountainous $90 \mathrm{~km}$ stretch between the two sites in a single year while remaining absent in a number of other dams surrounding Stellenbosch (Fig. 5). Both sites are in areas heavily impacted by humans, suggesting that separate human-mediated introductions are more plausible. Moreover, natural dispersal into two sites simultaneously also seems considerably less plausible than does a human-assisted event. That the Stellenbosch population occurs in a dam at the South African Department of Agriculture's Agricultural, Food, Quarantine and Inspection Services is also telling. Given that H. marmoratus lays eggs on aquatic vegetation (Passmore \& Carruthers, 1979, 1995; Channing, 2001), and is considered desiccation resistant (Withers et al., 1982; Schmuck \& Linsenmair, 1997; Bishop, 2004), transport on quarantined plant material seems probable.

The situation in the Durbanville dam is more complicated because $H . m$. verrucosus and the $H$. m. marmoratus colour patterns occur in approximately equal frequency, and a single individual with the H. m. taeniatus colour pattern was later collected but not sequenced (A. de Villiers, unpublished data). Two haplotypes found (KTH402 and KTH415) were also common 
in H. m. verrucosus (56\%) and H. m. marmoratus (39\%). The third haplotype found (D68) was rare in the dam (5\%), and was otherwise known only from the southern H. m. taeniatus population (Fig. 3, see Appendix S1). The rarity in the dam indicates that it may have been introduced more recently than the other haplotypes and has not gained a foothold in the population or that an H. m. taeniatus introduction was swamped by the other more established haplotypes.

The most plausible explanation of events for the Durbanville dam would be three independent colonizations (one for each morph/haplotype). Although less parsimonious, a maximum of six separate events is also possible because at least two haplotypes are shared across subspecies (Fig. 3) and these could have entered the population more than once via a different subspecies. An introduction from a single source is unlikely, as only the $H$. m. taeniatus subspecies was found to have all three haplotypes (Fig. 3, see Appendix S1), yet the dam contains all three colour morphs of which H. m. taeniatus is the rarest. Whatever the sequence of events, the present data for the Durbanville site provide stronger evidence of human-mediated jump-dispersal than for natural colonization.

\section{Modes of colonization}

Although human-mediated jump dispersal is clearly demonstrated, the actual means of colonization is unknown. Adults and eggs of H. marmoratus are desiccation resistant (Withers et al., 1982; Schmuck \& Linsenmair, 1997) so individuals could have been transported during either life stage. Accidental transport of adults on plant material (such as fruit or cut flowers) and the subsequent successful fertilization of eggs may have been the basis of the invasion. Alternatively, since females lay eggs on aquatic vegetation and fertilization is external (Passmore \& Carruthers, 1979, 1995; Channing, 2001), fertilized eggs may be transported on aquatic plants and released straight into water bodies, resulting in an adult population that is genetically homogenous for mitochondrial markers. Two of the dams (Durbanville and Strand) are located adjacent to golf courses with an abundance of ornamental vegetation, making egg transmission a plausible scenario. Moreover, the Strand dam is located adjacent to a nursery. Nursery plants are transported widely in South Africa (Richardson et al., 2003), and they are known to be involved in frog translocations elsewhere (Beard \& Pitt, 2005). Nonetheless, given the complexity of the Durbanville population, both the egg and the adult transfer scenarios seem plausible. Accidental discovery of the frogs by homeowners, and their subsequent release at an 'appropriate site' (Fuller, 2003) seems quite likely too.

In the case of Villiersdorp and Stellenbosch, natural colonization cannot be ruled out entirely, since these dams contain only H. m. verrucosus morphs. Furthermore, the desiccation resistance of the adults (Withers et al., 1982; Schmuck \& Linsenmair, 1997) suggests that natural long-distance dispersal could take place over land, and this pattern has been demonstrated in other amphibians using molecular data (e.g. Vences et al., 2003, 2004; Measey et al., 2007b). However, the substantial distance and mountainous terrain between the two dams, and their location in sites that have been heavily transformed suggests that human-mediated dispersal is substantially more plausible than natural dispersal. Quite how this might have happened is unknown.

\section{CONCLUSIONS}

When viewed in the context of range dynamic theory (Hengeveld, 1989; Suarez et al., 2001; Gaston, 2003), the genetic and morphological results present a strong case that the range expansion of $H$. marmoratus into Western Cape dams represents human-mediated jump dispersal rather than natural range expansion. In other words, $H$. marmoratus must be considered alien to these dams (see Pyšek et al., 2004 for rationale), and, given the densities encountered, a likely invasive (Richardson et al., 2000 provide definitions). While it seems likely that a parallel climate change-mediated range expansion is taking place in the southernmost natural population represented by H. m. verrucosus, the western, mixed-population colonizations of artificial impoundments represent a very different process.

While such complexity might not characterize other range expansions (see Parmesan, 2006 for review), these results caution against any simple interpretation of range expansions in an era characterized by a wide range of human interventions at all scales (Mack et al., 2000; Tilman et al., 2001; Sax \& Gaines, 2003; Millennium Ecosystem Assessment, 2005; Davies et al., 2006). Moreover, they highlight the utility of a phylogeographical approach to conservation biogeography (Whittaker et al., 2005), and particularly to the attribution of cause to novel range expansions in landscapes increasingly dominated by people.

In the specific case of this introduction, $H$. marmoratus was historically parapatric with its congener $H$. horstockii but the two species presently overlap substantially (Bishop, 2004). This creates the potential for hybridization and introgression (see Rhymer \& Simberloff, 1996), or competition for resources (see Kupferberg, 1997). The effects of H. marmoratus on ecosystem function remain unknown, but invasive amphibians have substantially altered ecosystem structure and function elsewhere (Kupferberg, 1997; Lampo \& de Leo, 1998; Crossland, 2000; Lever, 2001; Phillips \& Shine, 2004; Lobos \& Jaksic, 2005). With appropriate research (Simberloff, 2003), education of local communities, and involvement of nature conservation authorities, it is possible that the spread of this frog could be slowed and managed to minimize the impact of the invasion on the ecosystem and community.

\section{ACKNOWLEDGEMENTS}

We thank those who assisted with collections: Marius Burger, Félix Forest, Atherton de Villiers (Western Cape Nature Conservation), Barry de Villiers, Rikki de Villiers, Vincent Egan (Limpopo Provincial Government), Lorraine Egan, Ian Miller, Laché Rossouw, Jerry Theron (Mpumalanga Parks Board), Andrew Turner (Western Cape Nature Conservation), Jenny Underhill, and Simon van Noort. Thanks also to John Measey, 
Dave Richardson, and Andrew Turner for helpful discussions, Brian Chase for maps, and Marius Burger for photographs. Accommodation, assistance and access to sampling sites were provided by Buccaneers Backpackers, Blyde River Canyon Nature Reserve, Goukamma Nature Reserve, Lajuma Private Nature Reserve, and SAPPI Ltd. The DST-NRF Centre for Invasion Biology and the South African National Biodiversity Institute funded this study. Part of this work was carried out by using the resources of the Computational Biology Service Unit from Cornell University which is partially funded by Microsoft Corporation. Sampling was carried out under provincial permits from the Western Cape (001-202-00025), Eastern Cape (WRO 66/04WR), KwaZulu-Natal (4501/2005), Mpumalanga (MPR.5154), and Limpopo (CPM-005-00006).

\section{REFERENCES}

Bandelt, H.-J., Forster, P. \& Röhl, A. (1999) Median-joining networks for inferring intraspecific phylogenies. Molecular Biology and Evolution, 16, 37-48.

Bean, A.R. (2007) A new system for determining which plant species are indigenous in Australia. Australian Systematic Botany, 20, 1-43.

Beard, K.H. \& Pitt, W.C. (2005) Potential consequences of the coqui frog invasion in Hawaii. Diversity and Distributions, 11, 427-433.

Bishop, P.J. (2004) Hyperolius marmoratus Rapp, 1842. Atlas and red data book of the frogs of South Africa, Lesotho and Swaziland (ed. by L.R. Minter, M. Burger, J.A. Harrison, H.H. Braack, P.J. Bishop and D. Kloepfer), pp. 141-143. Smithsonian Institution, SI/MAB Series \#9, Washington D.C.

Blackburn, T.M., Cassey, P., Duncan, R.P., Evans, K.L. \& Gaston, K.J. (2004) Avian extinction and mammalian introductions on oceanic islands. Science, 305, 1955-1958.

Blows, M.W. \& Hoffmann, A.A. (2005) A reassessment of genetic limits to evolutionary change. Ecology, 86, 1371-1384.

Braack, H.H. (2004) Hyperolius horstockii (Schlegel, 1837). Atlas and red data book of the frogs of South Africa, Lesotho and Swaziland (ed. by L.R. Minter, M. Burger, J.A. Harrison, H.H. Braack, P.J. Bishop and D. Kloepfer), pp. 139-141. Smithsonian Institution, SI/MAB Series \#9, Washington D.C.

Brown, J.H. \& Lomolino, M.V. (1998) Biogeography. Sinauer Associates, Sunderland.

Calvalcanti, M.J. (2005) Mantel for windows, Version 1.18. Freeware available at http://life.bio.sunysb.edu/morph/.

Castley, J.G., Boshoff, A.F. \& Kerley, G.I.H. (2001) Compromising South Africa's natural biodiversity - inappropriate herbivore introductions. South African Journal of Science, 97, 344-348.

Channing, A.C. (2001) Amphibians of Central and Southern Africa. Cornell University Press, Ithaca, New York.

Clark, J.S. (1998) Why trees migrate so fast: confronting theory with dispersal biology and the paleorecord. American Naturalist, 152, 204-224.

Crossland, M.R. (2000) Direct and indirect effects of the introduced toad Bufo marinus (Anura: Bufonidae) on populations of native anuran larvae in Australia. Ecography, 23, 283-290.
Davies, R.G., Orme, C.D.L., Olson, V., Thomas, G.H., Ross, S.G., Ding, T.-S., Rasmussen, P.C., Stattersfield, A.J., Bennett, P.M., Blackburn, T.M., Owens, I.P.F. \& Gaston, K.J. (2006) Human impacts and the global distribution of extinction risk. Proceedings of the Royal Society of London Series B, Biological Sciences, 273, 2127-2133.

Deacon, H.J., Jury, M.R. \& Ellis, F. (1992) Selective regime and time. The ecology of fynbos nutrients, fire and diversity (ed. by R.M. Cowling), pp. 6-22. Oxford University press, Cape Town, South Africa.

Didham, R.K., Tylianakis, J.M., Hutchison, M.A., Ewers, R.M. \& Gemmell, N.J. (2005) Are invasive species the drivers of ecological change? Trends in Ecology \& Evolution, 20, 470474.

Dollar, E.S.J. (1998) Palaeofluvial geomorphology in southern Africa: a review. Progress in Physical Geography, 22, 325-349.

Drake, J.M. \& Lodge, D.M. (2004) Global hot spots of biological invasions: evaluating options for ballast-water management. Proceedings of the Royal Society of London Series B, Biological Sciences, 271, 575-580.

Dupanloup, I., Schneider, S. \& Excoffier, L. (2002) A simulated annealing approach to define the genetic structure of populations. Molecular Ecology, 11, 2571-2581.

Epperson, B.K. (2003) Geographical genetics. Princeton University Press, Princeton.

Folmer, O., Black, M., Hoeh, W., Lutz, R. \& Vrijenhoek, R. (1994) DNA primers for amplification of mitochondrial cytochrome c oxidase subunit I from diverse metazoan invertebrates. Molecular Marine Biology and Biotechnology, 3, 294-299.

Frost, D.R., Grant, T., Faivovich, J.N., Bain, R.H., Haas, A., Haddad, C.F.B., De Sa, R.O., Channing, A., Wilkinson, M., Donnellan, S.C., Raxworthy, C.J., Campbell, J.A., Blotto, B.L., Moler, P., Drewes, R.C., Nussbaum, R.A., Lynch, J.D., Green. D.M. \& Wheeler, W.C. (2006) The amphibian tree of life. Bulletin of the American Museum of Natural History, 297, 370.

Fu, Y.X. (1997) Statistical tests of neutrality of mutations against population growth, hitchhiking and background selection. Genetics, 147, 915-925.

Fuller, P.L. (2003) Freshwater aquatic vertebrate introductions in the United States: patterns and pathways. Invasive species Vectors and management strategies (ed. by G.M. Ruiz and J.T. Carlton), pp. 123-152. Island Press, Washington, D.C.

Funk, W.C., Blouin, M.S., Corn, P.S., Maxell, B.A., Pilliod, D.S., Amish, S. \& Allendorf, F.W. (2005) Population structure of Columbia spotted frogs (Rana luteiventris) is strongly affected by the landscape. Molecular Ecology, 14, 483-496.

Gaston, K.J. (2003) The structure and dynamics of geographic ranges. Oxford University Press, Oxford.

Giliomee, J.H. (2006) Conserving and increasing biodiversity in the large-scale, intensive farming systems of the Western Cape. South African Journal of Science, 102, 375-378.

Groves, R.H., Boden, R. \& Lonsdale, M.W. (2005) Jumping the garden fence. Invasive garden plants in Australia and their environmental and agricultural impacts. CSIRO Report prepared for WWF-Australia, Sydney. 
Harrison, J.A., Burger, M., Minter, L.R., de Villiers, A.L., Baard, E.H.W., Scott, E., Bishop, P.J. \& Ellis, S. (2001) Conservation assessment and management plan for Southern African frogs: final report. IUCN/SSC Conservation Breeding Specialist Group, Apple Valley, Minnesota.

Hastings, A., Cuddington, K., Davies, K.F., Dugaw, C.J., Elmendorf, S., Freestone, A., Harrison, S., Holland, M., Lambrinos, J., Malvadkar, U., Melbourne, B.A., Moore, K., Taylor, C. \& Thomson, D. (2005) The spatial spread of invasions: new developments in theory and evidence. Ecology Letters, 8, 91-101.

Hengeveld, R. (1989) Dynamics of biological invasions. Chapman and Hall, London.

Hengeveld, R. (1994) Small-step invasion research. Trends in Ecology \& Evolution, 9, 339-342.

Hewitt, G.M. (1996) Some genetic consequences of ice ages, and their role in divergence and speciation. Biological Journal of the Linnean Society, 58, 247-276.

Hewitt, G. (2000) The genetic legacy of Quaternary ice ages. Nature, 405, 907-913.

Higgins, S.I. \& Richardson, D.M.R. (1999) Predicting plant migration rates in a changing world: the role of long-distance dispersal. American Naturalist, 153, 464-475.

IUCN (2006) 2006 IUCN red list of threatened species. $<$ www.iucnredlist.org $>$. Downloaded on 1 February 2007.

IUCN, Conservation International, and NatureServe. (2007) Global amphibian assessment. <www.globalamphibians.org > Accessed on 16 April 2007.

Kirkpatrick, M. \& Barton, N.H. (1997) Evolution of a species' range. American Naturalist, 150, 1-23.

Kupferberg, S. (1997) Bullfrog (Rana catesbeiana) invasion of a California River: the role of larval competition. Ecology, 78, 1736-1751.

Lambiris, A.J.L. (1989) A review of the amphibians of Natal. Lammergeyer, 39, 1-121.

Lampo, M. \& de Leo, G.A. (1998) The invasion ecology of the toad Bufo marinus: from South American to Australia. Ecological Applications, 8, 388-396.

Lenormand, T. (2002) Gene flow and the limits to natural selection. Trends in Ecology \& Evolution, 17, 183-189.

Lever, C. (2001) The cane toad: the history and ecology of a successful colonist. Westbury Publishing, West Yorkshire, UK.

Levine, J.M., Pachepsky, E., Kendall, B.E., Yelenik, S.G. \& Hille Ris Lambers, J. (2006) Plant-soil feedbacks and invasive spread. Ecology Letters, 9, 1005-1014.

Lobos, G. \& Jaksic, F.M. (2005) The ongoing invasion of African clawed frogs (Xenopus laevis) in Chile: causes of concern. Biodiversity and Conservation, 14, 429-439.

Mack, R.N., Simberloff, D., Lonsdale, W.M., Evans, H., Clout, M. \& Bazzaz, F.A. (2000) Biotic invasions: causes, epidemiology, global consequences, and control. Ecological Applications, 10, 689-710.

Maddison, D.R. \& Maddison, W.P. (2000) Macclade 4: analysis of phylogeny and character evolution, Version 4.0. Sinauer Associates, Sunderland, Massachusetts.
Matthews, S. (2004) Tropical Asia invaded. The growing danger of invasive alien species. Global Invasive Species Programme, Cape Town, South Africa.

Matthews, S. (2005) South America Invaded. The growing danger of invasive alien species. Global Invasive Species Programme, Cape Town, South Africa.

McKinney, M.L. \& Lockwood, J. (1999) Biotic homogenization: a few winners replacing many losers in the next mass extinction. Trends in Ecology \& Evolution, 14, 450-453.

Measey, G.J., Galbusera, P., Breyne, P. \& Matthysen, E. (2007a) Gene flow in a direct-developing, leaf litter frog between isolated mountains in the Taita Hills, Kenya. Conservation Genetics, 8, 1177-1188.

Measey, G.J., Vences, M., Drewes, R., Chiari, Y., Melo, M. \& Bourles, B. (2007b) Freshwater paths into the ocean: molecular phylogeny of the frog Ptychadena newtoni gives insights into amphibian colonization of oceanic islands. Journal of Biogeography, 34, 7-20.

Midgley, G.F., Chapman, R.A., Hewitson, B., Johnston, P., De Wit, M., Ziervogel, G., Mukheibir, P., Van Niekerk, L., Tadross, M., Van Wilgen, B.W., Kgope, B., Morant, P.D., Theron, A., Scholes, R.J. \& Forsyth, G.G. (2005) A status quo, vulnerability and adaptation assessment of the physical socio-economic effects of climate change in the Western Cape. CSIR Report no. ENV-S-C 2005-073. CSIR Environmentek, Stellenbosch, South Africa.

Millennium Ecosystem Assessment (2005) Ecosystems and human well-being: biodiversity synthesis. World Resources Institute, Washington, D.C.

Minter, L.R., Burger, M., Harrison, J.A., Braack, H.H., Bishop, P.J. \& Kloepfer, D. (2004) Atlas and red data book of the frogs of South Africa, Lesotho and Swaziland. Smithsonian Institution, SI/MAB Series \#9, Washington D.C.

Mucina, L. \& Rutherford, M.C. (2006) The vegetation of South Africa, Lesotho and Swaziland, Strelitzia 19. South African National Biodiversity Institute, Pretoria, South Africa.

Nielsen, R. \& Wakeley, J.W. (2001) Distinguishing migration from isolation: an MCMC approach. Genetics, 158, 885-896.

O'Dowd, D.J., Green, P.T. \& Lake, P.S. (2003) Invasional 'meltdown' on an oceanic island. Ecology Letters, 6, 812-817.

Olden, J.D., Poff, N.L., Douglas, M.R., Douglas, M.E. \& Fausch, K.D. (2004) Ecological and evolutionary consequences of biotic homogenization. Trends in Ecology \& Evolution, 19, 18-24.

Parmesan, C. (2006) Ecological and evolutionary responses to recent climate change. Annual Review of Ecology Evolution and Systematics, 37, 637-669.

Passmore, N.I. \& Carruthers, V.C. (1979) South African frogs. Witwatersrand University Press, Johannesburg, South Africa.

Passmore, N.I. \& Carruthers, V.C. (1995) South African Frogs: a complete guide. Southern Books and Witwatersrand University Press, Johannesburg, South Africa.

Phillips, B.L. \& Shine, R. (2004) Adapting to an invasive species: toxic cane toads induce morphological changes in Australian snakes. Proceedings of the National Academy of Sciences USA, 101, 17150-17155. 
Posada, D. \& Crandall, K.A. (1998) Modeltest: testing the model of DNA substitution. Bioinformatics, 14, 817-818.

Pyšek, P., Richardson, D.M., Rejmánek, M., Webster, G.L., Williamson, M. \& Kirschner, J. (2004) Alien plants in checklists and floras: towards better communication between taxonomists and ecologists. Taxon, 53, 131-143.

Rhymer, J.M. \& Simberloff, D. (1996) Extinction by hybridization and introgression. Annual Review of Ecology and Systematics, 27, 83-109.

Richardson, D.M., Cambray, J.A., Chapman, R.A., Dean, W.R.J., Griffiths, C.L., Le Maitre, D.C., Newton, D.J. \& Winstanley, T.J. (2003) Vectors and pathways of biological invasions in South Africa - Past, present, and future. Invasive species Vectors and management strategies (ed. by G.M. Ruiz and J.T. Carlton), pp. 292-349. Island Press, Washington, D.C.

Richardson, D.M. \& Pyšek, P. (2006) Plant invasions: merging the concepts of species invasiveness and community invasibility.

Progress in Physical Geography, 30, 409-431.

Richardson, D.M., Pyšek, P., Rejmánek, M., Barbour, M.G., Panetta, F.D. \& West, C.J. (2000) Naturalization and invasion of alien plants: concepts and definitions. Diversity and Distributions, 6, 93-107.

Roe, B.A., Ma. D.P., Wilson. R.K. \& Wong, J.F. (1985) The complete nucleotide sequence of the Xenopus laevis mitochondrial genome. Journal of Biological Chemistry, 260, 9759-9774.

Rouget, M., Richardson, D.M., Cowling, R.M., Lloyd, W. \& Lombard, A.T. (2003) Current patterns of habitat transformation and future threats to biodiversity in terrestrial ecosystems of the Cape Floristic Region, South Africa. Biological Conservation, 11, 63-85.

Sax, D.F. \& Gaines, S.D. (2003) Species diversity: from global decreases to local increases. Trends in Ecology \& Evolution, 18, 561-566.

Schiøtz, A. (1999) Tree frogs of Africa. Edition Chimaira, Frankfurt, Germany.

Schmuck, R. \& Linsenmair, K.E. (1997) Regulation of body water balance in reedfrogs (Superspecies Hyperolius viridiflavus and Hyperolius marmoratus: Amphibia, Anura, Hyperoliidae) living in unpredictably varying savannah environments. Comparative Biochemistry and Physiology, 118A, 1335-1352.

Schneider, S., Roessli, D. \& Excoffier, L. (2000) Arlequin: a software for population genetics data analysis. Genetics and Biometry Laboratory, Department of Anthropology, University of Geneva, Geneva, Switzerland.

Simberloff, D. (2003) How much information on population biology is needed to manage introduced species? Conservation Biology, 17, 83-92.

Suarez, A.V., Holway, D.A. \& Case, T.J. (2001) Patterns of spread in biological invasions dominated by long-distance jump dispersal: insights from Argentine ants. Proceedings of the National Academy of Sciences USA, 98, 1095-1100.

Tilman, D., Fargione, J., Wolff, B., D’Antonio, C., Dobson, A., Howarth, R., Schindler, D., Schlesinger, W.H., Simberloff, D. \& Swackhamer, D. (2001) Forecasting agriculturally driven global environmental change. Science, 292, 281-284.
Trakhtenbrot, A., Nathan, R., Perry, G. \& Richardson, D.M. (2005) The importance of long-distance dispersal in biodiversity conservation. Diversity and Distributions, 11, 173-181.

Vences, M., Vieites, D.R., Glaw, F., Brinkmann, H., Kosuch, J., Veith, M. \& Meyer, A. (2003) Multiple overseas dispersal in amphibians. Proceedings of the Royal Society of London Series B, Biological Sciences, 270, 2435-2442.

Vences, M., Kosuch, J., Rödel, M.-O., Lötters, S., Channing, A., Glaw, F. \& Böhme, W. (2004) Phylogeography of Ptychadena mascareniensis suggests transoceanic dispersal in a widespread Africa-Malagasy frog lineage. Journal of Biogeography, 31, $593-601$.

Warren, M.S., Hill, J.K., Thomas, J.A., Asher, J., Fox, R., Huntley, B., Roy, D.B., Telfer, M.G., Jeffcoate, S., Harding, P., Jeffcoate, G., Willis, S.G., Greatorex-Davies, J.N., Moss, D. \& Thomas, C.D. (2001) Rapid responses of British butterflies to opposing forces of climate and habitat change. Nature, 414, 65-69.

Whittaker, R.J., Araújo, M.B., Paul, J., Ladle, R.J., Watson, J.E.M. \& Willis, K.J. (2005) Conservation biogeography: assessment and prospect. Diversity and Distributions, 11,3-23.

Wieczorek, A.M., Drewes, R.C. \& Channing, A.C. (2000) Biogeography and evolutionary history of Hyperolius species: application of molecular phylogeny. Journal of Biogeography, 27, 1231-1243.

Wieczorek, A.M., Drewes, R.C. \& Channing, A.C. (2001) Phylogenetic relationships within the Hyperolius viridiflavus complex (Anura: Hyperoliidae), and comments on taxonomic status. Amphibia-Reptilia, 22, 155-166.

Withers, P.C., Hillman, S.S., Drewes, R.C. \& Sokol, O.M. (1982) Water loss and nitrogen excretion in sharp-nosed reed frogs (Hyperolius nasutus: Anura, Hyperoliidae). Journal of Experimental Biology, 97, 335-343.

Editor: Andrew Storfer

\section{SUPPLEMENTARY MATERIAL}

The following supplementary material is available for this article:

Appendix S1 Haplotype frequencies for each clade of Hyperolius marmoratus from South Africa.

Appendix S2 Matrix of the estimated rates of gene flow for Hyperolius marmoratus from South Africa.

This material is available as part of the online article from: http://www.blackwell-synergy.com/doi/abs/10.1111/ j.1472-4642.2007.00428.x

(This link will take you to the article abstract).

Please note: Blackwell Publishing is not responsible for the content or functionality of any supplementary materials supplied by the authors. Any queries (other than missing material) should be directed to the corresponding author for the article. 